\title{
A review of building integrated photovoltaic: case study of tropical climatic regions
}

\author{
Mu'azu Mohammed Abdullahi', Abdullahi Abubakar Mas'ud', Ibrahim Abubakar Mas'ud', \\ Jorge Alfredo Ardila-Rey ${ }^{4}$, Firdaus Muhammad-Sukki ${ }^{5}$, Ridoan Karim ${ }^{6}$, \\ Ahmad Shakir Mohd Saudi ${ }^{7}$, Nurul Aini Bani ${ }^{8}$ and Asan Vernyuy Wirba ${ }^{9}$ \\ ${ }^{1}$ Department of Civil Engineering, Faculty of Engineering, University of Hafr-Albatin, Hafar Al Batin, Saudi Arabia \\ ${ }^{2}$ Department of Electrical and Electronics Engineering, Jubail Industrial College, Jubail, Saudi Arabia \\ ${ }^{3}$ Department of Mechanical Engineering, Shibaura Institute of Technology, Tokyo, Japan \\ ${ }^{4}$ Department of Electrical Engineering, Universidad Técnica Federico Santa María, Valparaiso, Chile \\ ${ }^{5}$ School of Engineering \& the Built Environment, Edinburgh Napier University, Edinburgh, United Kingdom \\ ${ }^{6}$ Department of Business Law \& Taxation, Monash University Malaysia, Subang Jaya, Malaysia. \\ ${ }^{7}$ Center for Water Engineering Technology, Malaysia France Institute, Universiti Kuala Lumpur Bandar Baru Bangi \\ Selangor, Malaysia \\ ${ }^{8}$ UTM Razak Faculty of Technology and Informatics, Universiti Teknologi Malaysia, Malaysia \\ ${ }^{9}$ Department of Management Information Technology, Jubail Industrial College, Jubail, Saudi Arabia
}

\begin{tabular}{l}
\hline Article Info \\
\hline Article history: \\
Received Mar 27, 2020 \\
Revised Nov 25, 2020 \\
Accepted Dec 13, 2020 \\
\hline
\end{tabular}

Keywords:

Building integration

Photovoltaic

Solar energy

Tropical climate

\begin{abstract}
The building integrated photovoltaic (BIPV) system have recently drawn interest and have demonstrated high potential to assist building owners supply both thermal and electrical loads. In this paper, the BIPV technology has been reviewed, in terms of its performance, efficiency and power generation capacity. Specifically, the applications of the BIPV in tropical climate regions have been discussed, together with its prospects and challenges. For these schemes to be implemented in a tropical climatic region, the following issues must be considered: 1) Certain studies must be done relating to electrical load demand, predicted PV output, location of the buildings and its integration and constraints associated with roof design; 2) For the highest energy production from solar PV, the solar collectors need to be with the right tilt depending on the location; 3) Design criteria such as safety, efficiency, durability, flexibility and constructive issues need to be considered; 4) The government of such countries must train electricians and carpenters on PV installations; 5) The BIPV roofing must perform same function as normal roofing materials, such as noise protection, water tightness, insulation and climate protection, and 6) As practiced around the world, these countries must establish design standards for the BIPV.
\end{abstract}

This is an open access article under the CC BY-SA license.

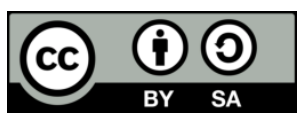

\section{Corresponding Author:}

Abdullahi Abubakar Mas'ud

Department of Electrical and Electronics Engineering

Jubail Industrial College

PO Box 10099, Jubail 31961, Saudi Arabia

Email: masud_a@jic.edu.sa

\section{INTRODUCTION}

In the contemporary world, the global community apprehended that the non-sustainable energy sources (e.g. fossil fuel) will be available only for a limited period. Consequently, the urgency to avail sufficient renewable energy sources has already become an issue of discussion. One such source, commonly 
regarded as a complete clean energy is the solar energy [1]-[3]. Recently, due to the development of new regulatory frameworks coupled with rising densification of cities, there is a need to acknowledge the significance of applying solar technology for buildings [4]-[6]. In most European countries, buildings account for $40 \%$ of the total energy use [7], but still the situation has not improved despite improved technologies and building codes that make such buildings more comfortable. Due to the global world population growth, energy demand in buildings has raised up to rise up to $50 \%$ by 2020 , with the global building region anticipated to double by 2050 [8].

It is vital to understand that solar energy can play a vital role in modern buildings such as solar heating and cooling and photovoltaic (PV) powered [9], [10]. Already, architectural firms are opting for this trend, joining hands with energy experts to design and construct totally solar buildings [7]. The main characteristics of solar PV technology and building integration technology involve a wide range of disciplines. Systemization and deliberate efforts from solar manufacturers, construction companies, designing institutions, property developers and component construction department are necessary in order to achieve the utilization of solar energy and building integration technology. The role of regulations department and national policies cannot be omitted either. For years, many problems have arisen in developing renewable energy, including the issues of energy security and the threat of climate change which eventually also serve as the prime factors for development of such energy sources. The sun is the greatest substantial sustainable power source [11]. The concentration of greenhouse gas due to the abuse of fossil fuel usage has resulted in global temperatures and environmental degradation. The declining oil and gas supplies, coupled with the increasing concerns for the global effect of $\mathrm{CO}_{2}$, gave rise to green buildings (i.e. buildings designed and constructed so as to reduce their environmental impact) [12].

A tremendous effort has to be made to reduce energy demand of civil structures by applying effective measures that maximize energy usage produced by PV [13]. From time to time, the technical developments of optical, electronic, thermal, and architectural and fluid mechanics also served the purpose to make the solar energy and integration technology more lucrative. Over the years, solar panels have produced green energy on the rooftops of buildings i.e. by integrating the PV elements into the building structure, thereby transforming it into a generating set [14]. By 2020, the industry of building integrated PV is predicted to reach $11.1 \mathrm{GW}$ [15]. In particular, Europe will have the highest utilization of this technology. In another perspective, James et.al [16] recommend several ways to help increase the relevance and growth of solar PV in buildings. These include the reduction in the PV prices and the increased interest in policies on solar energy. There is also little commercialization with full functionality of building materials. Generally, the fundamental reason for the limited BIPV deployment is that the average market price of installed systems is presently higher than for rack-mounted PV.

Nonetheless, it cannot be denied that an advanced construction process of integration technology is required to develop the solar energy. The complex construction of the waterway and circuits are another method, other than the conventional one, in order to install and debug tasks of solar equipment. Nevertheless, solar energy remains the single extensive alternative energy resource as it offers more economic benefits, safety and secure process of energy production and environment friendliness. Therefore, the acceptance of solar energy is more apparent than any other alternative energy resources [9]. Over the years researchers have investigated the application of BIPV in tropical areas[17]-[19]. Recent study [20] shows that for tropical climate, the BIPV can increase the quantity of heat transfer through the building structure, thereby influencing the inner temperature and discomforting the residents. Another study [21] investigated the heat comfort and adaptive actions for occupants in naturally ventilated areas and proposed certain adjustments to the acceptance of the heat burden on the occupants; one is the improvement of the velocity of the air and adopting cross-ventilation, and the other is reducing the insulations related to the building. Aaditya and Mani [22] proposed the development of a climatic responsive BIPV scheme. For tropical climates, the design of the building should be done in such way to reduce heat gain while enhancing heat loss within buildings. The best option is to design a BIPV with controlled ventilation, higher heat mass and shading. In another study, Gut and Ackerknecht [23] discussed the optimum building scenarios in tropical and subtropical regions. The wind orientation plays a big role in the building's thermal insulation. It was suggested that proper coatings in roofings and reflections in ceilings could reduce overheating. Ghazali and Abdul Rahman [24] investigated the application of solar tracking in tropical climates. For BIPV, the solar tracking not only enhances the PV output power but it also helps to reduce direct sun radiation on building envelopes. Recently, Lawal [25] investigated the energy conservation in buildings located at the southern part of Nigeria and concluded that for tropical climates, special consideration should be made in such a way that building are constructed with materials possessing high heating storage capacity and avoiding sustained lagging. The lag can create unwanted re-radiation of heat that may cause discomfort to the residents. Despite all the developments, little work has been made on the implementation of BIPV for tropical areas due to several factors such as high cost of installation and lack of awareness in the building industry. 
One example of a tropical climatic region is Nigeria. It is a country that has abundant unutilized solar radiation. The average daily solar radiation in the northern region is $7 \mathrm{kWh} / \mathrm{m}^{2}$ while in the southern part of the country is about $4 \mathrm{kWh} / \mathrm{m}^{2}$ [26], [27]. Though, Nigeria has improved local manufacturing of PV [28], a lot need to be done to support this market. Solar energy is frequently utilized in Nigeria for street lighting and domestic energy consumption, however no visible solar technology integration within buildings can be remarked for both solar heating and solar power. Therefore, this paper attempts to review and discuss BIPV integrations advancements in many countries, using Nigeria as a case study, in order to suggest and recommend the further development of such technology in tropical climates. In such process of reviewing, this paper also evaluates the challenges associated to BIPV technology, and analyses future improvement options to accommodate it in the national energy mix.

\section{BUILDING INTEGRATED PV}

There are two main types of solar PV integration in buildings. These are the building integrated PV system (BIPV) and the building attached PVs (BAPV) [29]. However, there is misperception concerning the actual definition of BIPV within the building industry and such confusion extends to the PV industry. BIPV are delineated as PV modules feasible to assimilate within the building envelope by reinstating the normally used materials of the building, [30] while BPAV are PVs attached to the building with no direct influence on any structural function [31]. As stated in the literature [32], there are certainly many parameters that need to be carefully inspected in solar PV building integration such as: (1) buildability; (2) design; (3) durability; (4) environmental factors; (5) maintenance; (6) performance safety, and (7) standard regulations.

The classification of BIPV is done based on the type solar cell, their application and market availability [29]. BIPV products are categorized into four; i.e. solar cell glazing, tiles, foils, and modules [33]. A complete schematic diagram is illustrated in Figure 1.

\section{BIPV SYSTEM}

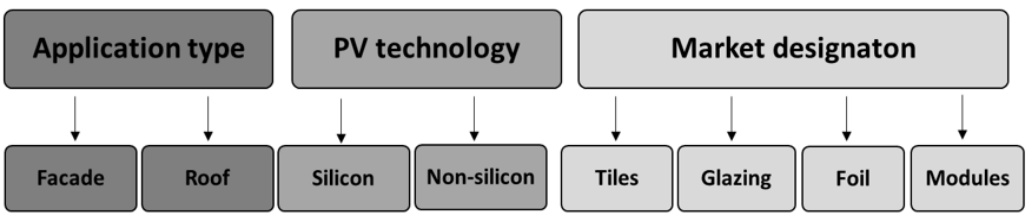

Figure 1. BIPV classification. Adapted from [33].

BIPV refers to PV components substituting the normal building components through its incorporation to the usual building envelope [34], thus decreasing heat spread over the building [35]. It is quite established that the productivity of PV modules declines with the rise in temperature, and many studies have been conducted to solve this problem. One solution, as suggested in literature [29], is that the PV modules efficiency might be improved through heat absorption at the rear of the PV module, using fluid or air to generate a convention mechanism, thereby opening new inputs for hot or cold area around the PV. Another method to enhance the performance of the PV modules is through shadowing effect or changing the direction or slope of the PV.

Chow et al. [36] modeled a $260 \mathrm{~m}^{2}$ BIPV system that was analyzed using multi-platform building performance software (ESP-r). The simulation was done by creating an air gap of $250 \mathrm{~mm}$ between the building and the PV. The air-gap permits the air to be heated so that it can be utilized for water pre-heating. Three scenarios were implemented; i.e. BIPV with cooling of cells, BIPV with air heating, and BIPVwithout any integration. The year-long energy outputs from those three situations were reported being 83,680, 83,584 and 83,205 MJ, correspondingly.

Jiménez et al. [37] developed a BIPV component for heat transfer via stochastic differential equation. A sequence of experiments made up of 121 polycrystalline PV modules covering $1.44 \mathrm{~m}^{2}$ areas was implemented in the model. The authors found that this technique is beneficial in modeling nonlinear stochastic heat occurrence in BIPV.

Pantic et al. [38] examined 3 configurations of the BIPV/thermal (BIPVT) system. Configuration one was the base case of unglazed BIPV with air consistently run underneath it. Configuration two involves 
$1.5 \mathrm{~m}$ vertical glazed solar collected and incorporated into the system. And, the third configuration is the addition of a complete glazing on top of the PV. It was observed, from these configurations, that heating, ventilation, air conditioning (HVAC), and water pre-heating can be achieved using the first configuration. Heat energy efficiency can be achieved through the second and third configuration. In the third configuration, electric power creation was considerably reduced due to the overheating of PVs.

Corbin and Zhai [39] examined a novel BIPVT consisting of absorbers, heat storage and pump. The authors developed two computational fluid dynamics (CFD) models. The first model is a standard model adjacent to the top surface, while the second comprises liquid-cooled-tube absorber for recovery effects. At the end of the research, it was shown that the later BIPVT has up to 5.3\% better electrical efficiency. The whole productivity of the system was found to be within 19-34.9\% respectively.

Peng et al. [40] studied the architectural design features of BIPV systems as follows: (i) design procedure, (ii) life-span of the system and (iii) suitability of the BIPV. They also designed a new arrangement to solve matters related to the proper care of the PV components. The authors concluded that technology, aesthetics, function and cost are key features. Urbanetz et al. [41], examined the annual electricity generation of two systems. One is the $10 \mathrm{kWp}$ BIPV system and the other is a curved $12 \mathrm{kWp} \mathrm{PV} \mathrm{system.} \mathrm{The} \mathrm{first} \mathrm{is} \mathrm{a}$ thin film a-Si technology made up of 24 elastic modules, while the second consisted of 88 flexible panels made of thin-film a-Si layers. Specific findings indicated that the $10 \mathrm{kWp}$ BIPV system holds more yearly energy revenue than the second one.

Zogou and Stapountzis [42] conducted the experimental investigation of the transient heat analysis for the BIPV system, using the PV module and the Plexiglas module. The authors carried out the experiment in 3 main stages. No natural convection (i.e. fan) in the first stage, while fans were operated at $110 \mathrm{~m}^{3} / \mathrm{h}$, and $190 \mathrm{~m}^{3} / \mathrm{h}$ flow for the second and third approaches respectively. Findings show that the temperature variation of air for various approaches was between $4.5^{\circ} \mathrm{C}$ and $8.9^{\circ} \mathrm{C}$ with the power ranged between $74.7 \mathrm{~W}-85.5 \mathrm{~W}$. Observation on the least panel temperature in mode 3 suggested that total cooling and transfer of heat rises as more air flows.

Yoon et al. [43] developed the pioneer BIPV application, with thin-film a-Si cells mounted on the windows. The authors observed the system for about 2 years and noted the monthly power generation sum to be $48.4 \mathrm{kWh} / \mathrm{kWp}$. Additionally, the annual generation amount is $580.5 \mathrm{kWh} / \mathrm{kWp}$. The simulation effects confirm that particular electrical energy generation for the system can reach up to $47 \%$ if the azimuth and shading effects are adjusted.

There are two BIPV/BAPV systems examined by Santos and Rüther [10] on the possibility of implementation of both systems for a current domestic building. One is the $2.25 \mathrm{kWp}$ c-Si system and the other is the $10 \mathrm{kWp}$ a-Si system. The findings revealed that $87 \%$ of the PV sets can create $95 \%$ of the peak hypothetical potential. In addition, only $3 \%$ of the systems were able to create $85 \%$ of the peak theoretical output value. Their results show that the PV kits are able to produce separate yearly energy demand for the whole buildings.

Ban-Weiss et al. [44], examined the cooling system and electricity production saving effects of PV modules, made up of thin-film a-Si triple junction solar cells. After installation of BIPV, the solar absorptance of roof reduces from 0.75 to 0.38 . The outcomes show that the daily energy output range of the system appears to be $0.4 \mathrm{kWh} / \mathrm{m}^{2}$ in the summer and $0.15 \mathrm{kWh} / \mathrm{m}^{2}$ in the winter. They further concluded that the BIPV system mounted in an office building in Phoenix, Arizona, USA would cause $9.6 \mathrm{kWh} / \mathrm{m}^{2}$ yearly cooling and $2.9 \mathrm{MJ} / \mathrm{m}^{2}$ heating power savings.

Han et al. [45] compared the performance of 2 different types of PVs, i.e. conventional clear façade and ventilated double-sided. The conventional clear façade is a PV layer made up of a-Si PV cell, while the second one is a transparent glass and screen on the façade. The authors show that the interior air temperature for the ventilated double-sided PV scheme was lower than the conventional clear façade. Moreover, their results show that the module temperature on the efficiency of PV was small for all these modules. Apart from power generation, the ventilated double-sided PV can contribute to power savings via decreasing the load on the air-conditioning.

Drif et al. [46] shows a technique for power evaluation losses as a result of the partial covering of BIPV systems. In this scenario, 9 sub-arrays of PV modules were split to $2.5 \mathrm{kWp}$ each. For a 1 subgenerator, measurements were $10.62 \mathrm{kWh}$ /day, against theoretical measurements of $12.41 \mathrm{kWh}$. The authors concluded that the daily power losses caused by covering were $1.79 \mathrm{kWh}$. That is equivalent to $14.4 \%$ of the overall BIPV system power generation.

The $22 \mathrm{PV}$ arrays performance under different tilt and orientations were investigated by Wittkopf et al. [47]. These systems comprise an on-grid BIPV system of $142.5 \mathrm{kWp}$. The monthly average performance ratio was recorded to be 0.81 and the monthly mean power generation was $12.1 \mathrm{MWh}$. The authors also studied the influence of different criterion on the BIPV performance such as irradiance changes, partial covering, PV temperature changes. 
Defaix at al. [48] evaluated the BIPV's technical potential within the EU-27 using the available statistical fingerprints. The BIPV is assumed to be a mixture of crystalline wafer. The performance ratio for the thin film of PV panels was 0.8 , while the mean of efficiency was $17.9 \%$. The obtained for the BIPV's potential within the EU was $951 \mathrm{GWp}$ and the annual potential power production was $840 \mathrm{TWh}$. This power can meet approximately $22 \%$ of the expected electricity needed by the European continent.

The cost-effectiveness of BIPV was investigated by Wei et al. [49] and it was compared with domestic solar water heater (DSWH). The lifespan of the BIPV system is approximately 25 years with power generation capacity of $140 \mathrm{kWh} / \mathrm{m}^{2}$. The authors were able to show that the BIPV system was more favorable with $6 \mathrm{~m}^{2}$ roof area and the domestic solar water heater (DSWH) of the BIPV is more beneficial as it can be better installed if the cost of the BIPV is RMB $0.9 / \mathrm{kWh}$.

López, and Sangiorgi [50] examined the influence of BIPV modules on human comfort using identically two $10 \mathrm{~m}^{2}$ rooms. Their first trial shows that the thin-film related PV modules have better performance compared to hygro-thermal comfort. Amorphous silicon (a-Si) PV modules have higher energy generation capacity. In terms of heating and lightning, CIS PV modules appear to have higher energy consumption. They conducted another test using the m-Si PV modules and found that it has higher lightning demand than the CIS modules. The m-Si PV modules have higher energy generation within 0.09-1.31 $\mathrm{kWh}$ /day as compared to the CIS PV modules.

In another study, Yang and Athienitis [51] examined BIPVTs thermal efficiency using two inlets. Results show two inlet panels having 5\% higher thermal effectiveness in comparison to a single input semitransparent panel. Apart from this, they concluded it is preferable to design a simple and cheap two inlet panel. The authors also carried out the performance assessment of BIPVT having different inlets. They developed a correlation regarding some inlet solar simulators and BIPVT prototype. Findings show that a four inlet type has $7 \%$ higher efficiency when compared to one inlet type.

Bigaila et al. [52] investigated a BIPVT system made up of 1030 x $548 \mathrm{~mm} \mathrm{~m}-\mathrm{Si}$ panel, 5 x $10 \mathrm{~cm}$ insulation, and $7 \mathrm{~cm}$ air gap. The experiment was conducted with 8 lamps; each has a maximum power of 4.6 $\mathrm{kW}$. The lamps can be attuned within $0^{\circ}-90^{\circ}$. Their results show that the solar heat collectors possess similar efficiency to the unglazed thermal collector (UTC), with up to $15 \%$ higher efficiency.

Eke and Demircan [53] studied the shadowing effect of BIPV on a structure comprising five floors, and each floor was installed with a three a-Si (triple junction amorphous PV) modules. The results show that the yearly energy rating for the first array is $1072 \mathrm{kWh} / \mathrm{kWp}$ while for the second array is $885 \mathrm{kWh} / \mathrm{kWp}$. Low electricity output was measured towards the end of the year due to the lowest radiation at that time. It was concluded that the shading effect has substantial effect due to the building direction, PV tilt angle and the ambient temperature.

Timchenko et al. [54] applied certain system specifications (i.e. $1.5 \mathrm{~m} \times 0.7 \mathrm{~m} \times 0.1 \mathrm{~m}$ size) to evaluate open channel PV. Three different two-wall configurations were used, (i) uniform, (ii) staggered, and (iii) non-uniform. Their results show that there must be alternative inputs between hot and cold zones in order to improve the heat transfer.

Ritzen et al. [55] mentioned four vital aspects of PV market such as BIPV, PV efficiency, electrical storage and PV market. Some tests were carried out under different conditions of condensation, coloring and backstring ventilation. Test 1 showed that the output of PV varies between 10-40\% on autumn and spring period respectively. Due to $100 \%$ relative humidity, the PV output was reduced by $0.5 \%$. Test 2 comparing between black module and color module, there is a difference of $10 \%$ for the PV output. Vertical and zig-zag type lineup showed a difference of $62 \%$. There were better advantages of zigzag type module lineup during the autumn-spring period.

Chen and Yin [56], designed a BIPVT system for heating liquid with water through cooling the PV. The PV module was developed by aluminum high density polyethylene that contained aluminum water tubes. In this situation, there is reduction of temperature through heat transfer from PV to the water tubes. Laboratory results indicated enhanced energy conversion efficiency. There is almost $5 \%$ reduction in the module temperature. There is also a flow rate increase by $500 \%$. At particular flow measure of $150 \mathrm{ml} / \mathrm{min}$, the electricity production was of $32.94 \mathrm{~W}$ and $44.91 \mathrm{~W}$ correspondingly for $800 \mathrm{~W} / \mathrm{m}^{2}$ and $1000 \mathrm{~W} / \mathrm{m}^{2}$.

Lu et al. [57] experimentally developed a new PV parabolic reflector with a concentration ratio of 2, suitable for building façade applications. In this paper, a broad enclosed test was conducted to assess the thermal and electrical categorization of the developed scheme. The factors affecting the output power of the system were also discussed. In comparison to the non-concentrating PV, the results indicate that Building Façade Integrated Asymmetric Compound Parabolic Photovoltaic concentrator (BFI-ACPPV) scheme has the capacity to raise the output power per unit area of the solar cell by 2 . The results further indicate that the BFIACPPV coupled with phase change material have higher efficiency in comparison with a non-phase change system. The results were obtained at solar radiation intensity of $280 \mathrm{~W} / \mathrm{m}^{2}$ and $69 \mathrm{~W} / \mathrm{m}^{2}$. At $280 \mathrm{~W} / \mathrm{m}^{2}$, the measured power output is $3.51 \mathrm{~W}$. 
Table 1 shows a summary of literature review regarding the BIPV systems. In summary, the BIPV is expected to be highly beneficial in the future design of buildings. According to literature, and in many countries, BIPV is capable of satisfying building energy requirements of 70\% [58]. In most BIPV researches and applications, monocrystalline solar PV has been widely used due to its higher efficiency and heat tolerance. The façade application is mostly to take advantage of shading and heat insulation on walls. In tropical climates, the thermal shielding effect of BIPV can reduce space cooling by around 30\% [11]. Either as a rooftop or façade application, the BIPV can, in the long term, have good investment returns. BIPV can also give buildings better visual appearance and ensure reduced electricity tariff. One major issue is the likelihood of the BIPV experiencing higher temperatures, because of their attachment to the building structure, thereby reducing the conversion efficiency of the PV module. Some highlighted barriers that may hinder the development of BIPV [59], include: i) lack of awareness of the BIPV especially in developing countries as a means of energy saving and reduction of greenhouse gas emission, and ii) lack of economic and technical solutions about BIPV technology.

Generally, incorporating BIPV to the building structure give rise to net-zero energy buildings. This depends on many factors such as building topology, availability of surfaces for polarization, total energy needs and techno-economic feasibility analysis.

Table 1. Summary of the BIPV systems

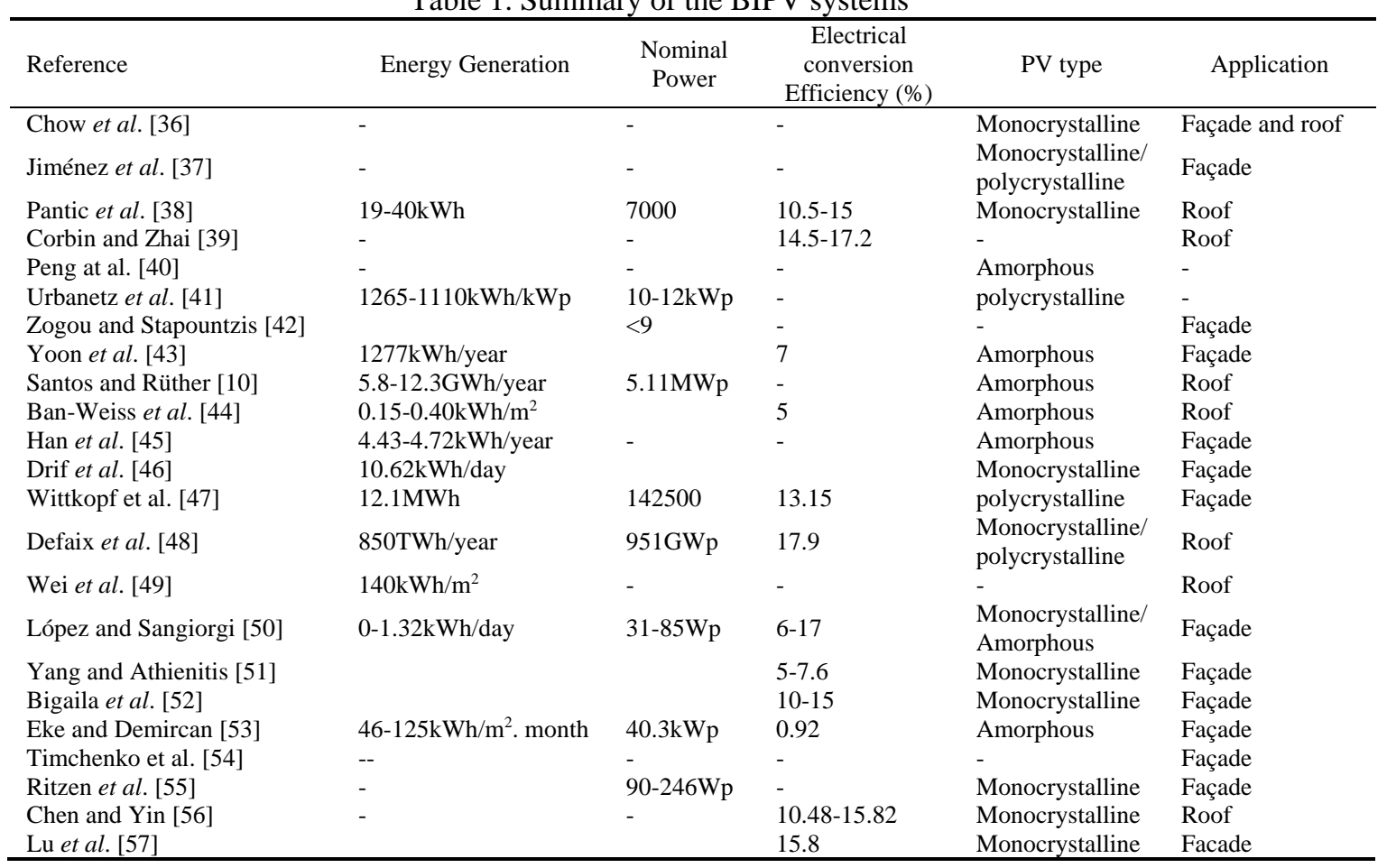

\section{PV PANELS BUILDING INTEGRATION CONFIGURATIONS}

In this section, it is explained the results of research and at the same time is given the comprehensive discussion. Results can be presented in figures, graphs, tables and others that make the reader understand easily [2], [5]. The discussion can be made in several sub-chapters.

\subsection{Slope glazing}

Sloped glazing includes atriums, titled walls, sunspace or green house on top overhead of the walls. Such glazing also incorporates framed aluminum, coated with tinted frames, glasses with lamination, or plastic glazing in case of semi-transparent glazing systems. One of the examples of Atrium with integrated amorphous silicon PV panels has been shown in Figure 2, which is taken from the Doxford International Park, situated in Sunderland. PV panels majorly work for the transmission of the ample amounts of diffused light, therefore, day lighting is essential solution of buildings.

It is always desirable to have a diffused day lighting condition in office buildings in order to produce sufficient energy, however, excessive sunlight can cause generates overheating which eventually ends up excessive glare [60]. Regular glass provides more transparent basis than the PV glazing glass (5-10\% 
transparency). Regarding such transparency, excessive daylight substantially impacts in the building. Therefore, a balanced design should be the prime concern in order to advance PV glazing and the daylight in the building.

For BIPV, and in order to achieve the maximum supply of daylight, window is always advised to be $20 \%$ of the facade area on the south orientation in the northern hemisphere. According to [61], that number varies when the systems are built with crystalline silicon (increase to $24 \%$ ) and thin-film PV panels (increase to $32 \%$ ).
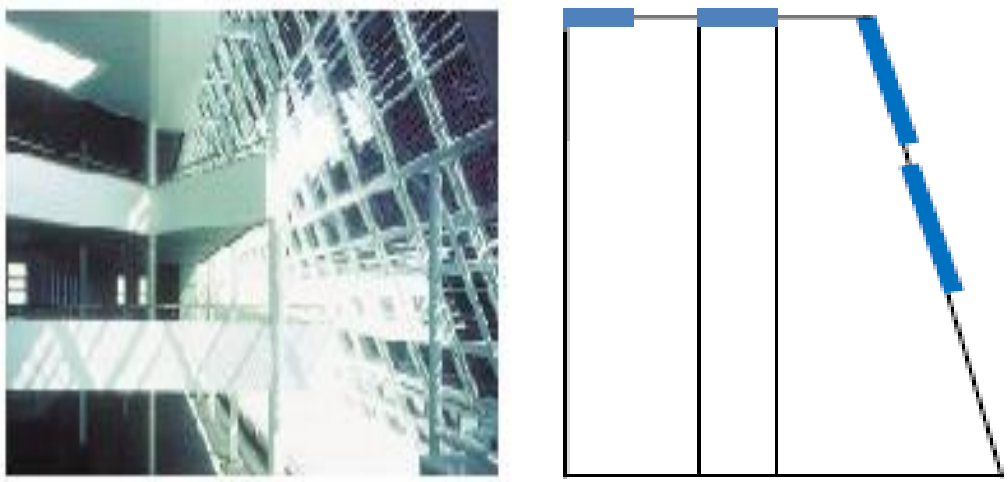

Figure 2. Atrium with integrated amorphous silicon PV panels in the solar office of Doxford International Park, in Sunderland, UK [62].

\subsection{Vertical panel}

Vertical orientation of the PV panel reduces the results of PV output, because they possess the same construction characteristics as atria/sloped-glazing. Curtain walls are appropriate for a wide range of PV products; they contain opaque surfaces (spandrel areas) in multi-story buildings, whereas, materials of nontransparent products can also be used. To adopt such configuration, compromises should be made between overheating, density, and the glare of PV panels that are employed in the façade. Example of such configuration at APS office building situated in California is shown in Figure 3.
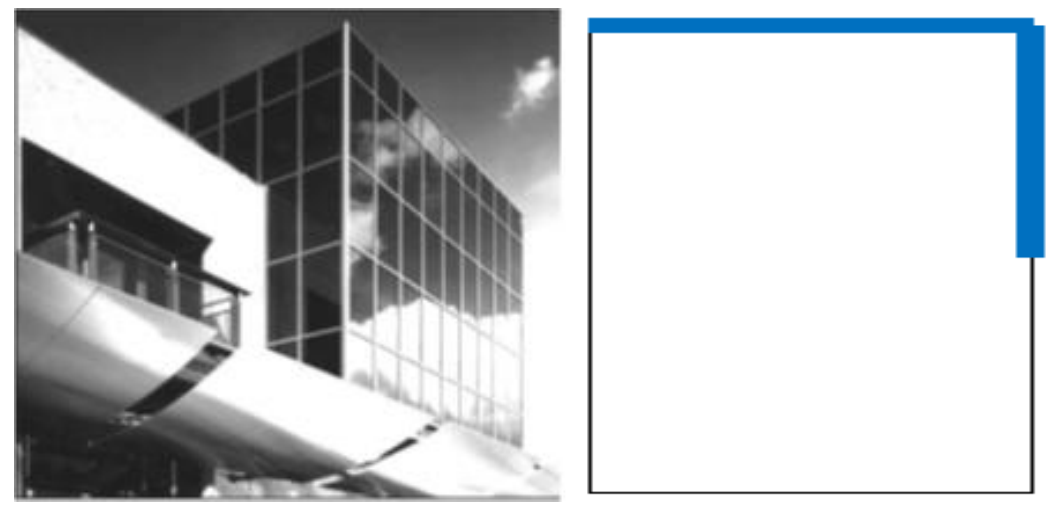

Figure 3. APS office facility in California [60]

Amorphous PV modules shown in Figure 3 at the APS Facility in California with integrated PV panels, are generally combined with the panels that are constructed with vision glasses and framed with standard curtain wall [60]. Just like the spandrel panels in a multi-story curtain wall, PV modules are also sealed at the back with an opaque insulating panel. If the PV glazing can be formed in a way where the clear glass can be adjusted between the upper and lower part of the entire construction, then the glare can be prevented, as shown in Figure 4. In addition, such structure provides the necessary daylight with the view 
sight as the clear glass is situated in the middle part of it. As seen in Figure 4, PV panels do not take the whole space of the window and provide enough room for the clear glass.

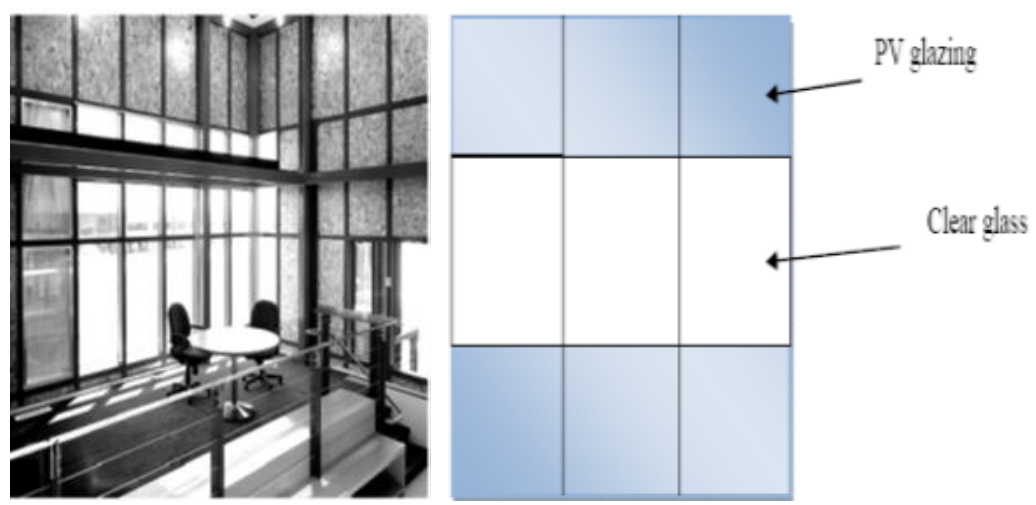

Figure 4. APS Facility in California, interior space.

\subsection{Inclined walls with PV panels}

In this particular type of arrangement, the efficiency of PV panels is enhanced as they are tilted, that includes complexity in the design of the building. Figure 5 provides a detailed picture of the inclined PV panels at the University of North Umbria, UK [62]. The most amazing thing of this configuration is that such design can be utilized with any kind of commercial PV panels, which means, its use is not limited to window-based technology, because such design creates a degree of self-shading.

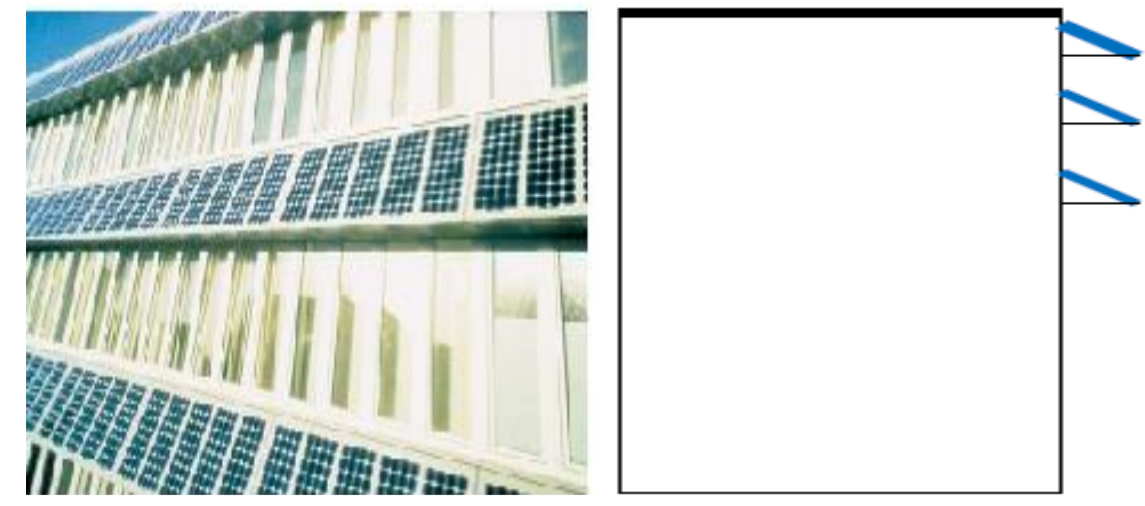

Figure 5. Inclined PV panels at the University of Northumbria, UK [62].

\subsection{Fixed Sunshade}

Configurations such as shown in Figure 6 can enhance the shading benefits in order to reduce glare. However, such structures can avoid the proper access of daylight. In this kind of configuration, mostly standard PV modules are attached using a metal frame to the envelope of the building. The construction of such configuration is also easy as it takes the same procedure as installing regular sunshades on the building.

Nonetheless, the main advantage of this configuration is that it can be constructed even with shading from adjacent buildings and, in such case, all kinds of PV panels are functional. The nature of this configuration is more convenient as it provides different alternative choices to the designers and maintenance [62]. In Figure 7, the example is taken from a commercial office building in Switzerland, built in 1993 which shows how a fixed sunshade can be operated in an efficient way.

The tilting of the panels increases the efficiency of the PV panels. Moreover, in such configuration, PV laminates are accommodated in a way that can provide a flat surface for shading elements and also rear ventilation that dissipates the generated heat. 

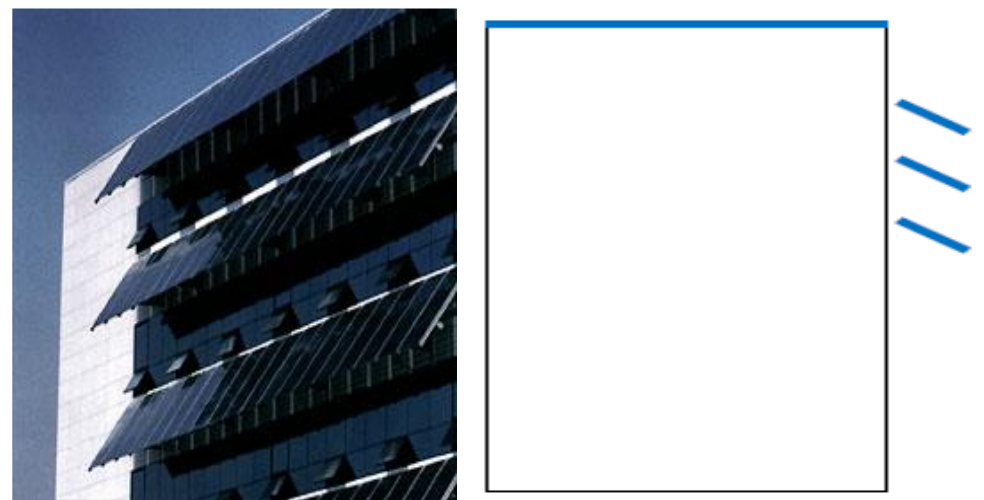

Figure 6. Samsung commercial office building in Seoul, Korea, integrated in fixed sunshades and the roof of the system [63]
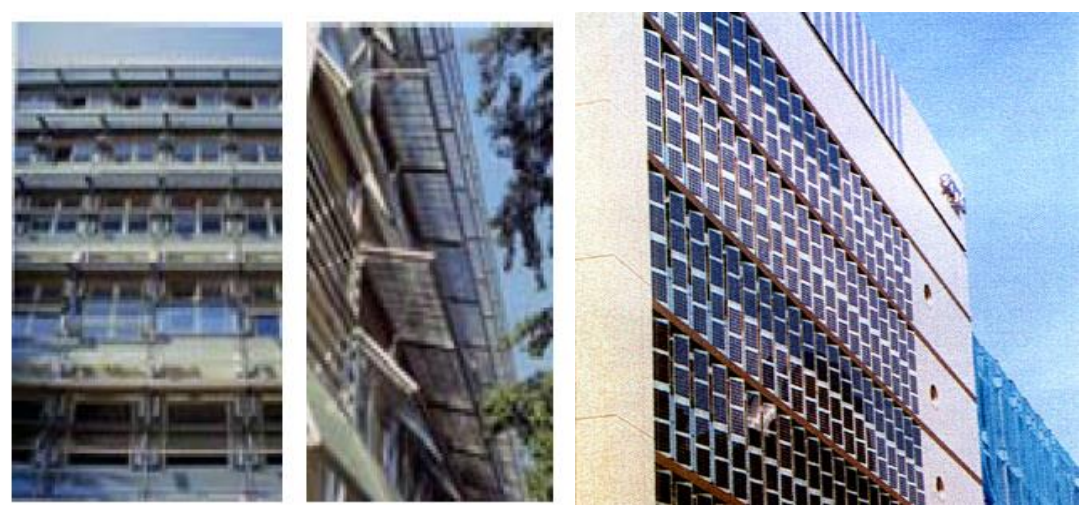

Figure 7. Fixed sunshades in the SUVA building. A commercial office building in Switzerland, built in 1993 [64]

\subsection{Moveable sunshades}

Moveable sunshades are the most efficient configuration in regards to solar panel, as it can achieve the greatest efficiency with all the advantages of fixed sunshades. Such configuration works with the change of tilting according to solar radiation level. Such adjustments can be made either manually or electrical and mechanical means.

Example of moveable sunshades applied in a commercial office building is shown in Figure 8 which is situated in Switzerland. It is true that due to the added feature of moving sunshades, such configuration may be a little expensive; nevertheless, the efficiency of producing energy is greater than other solar configurations.
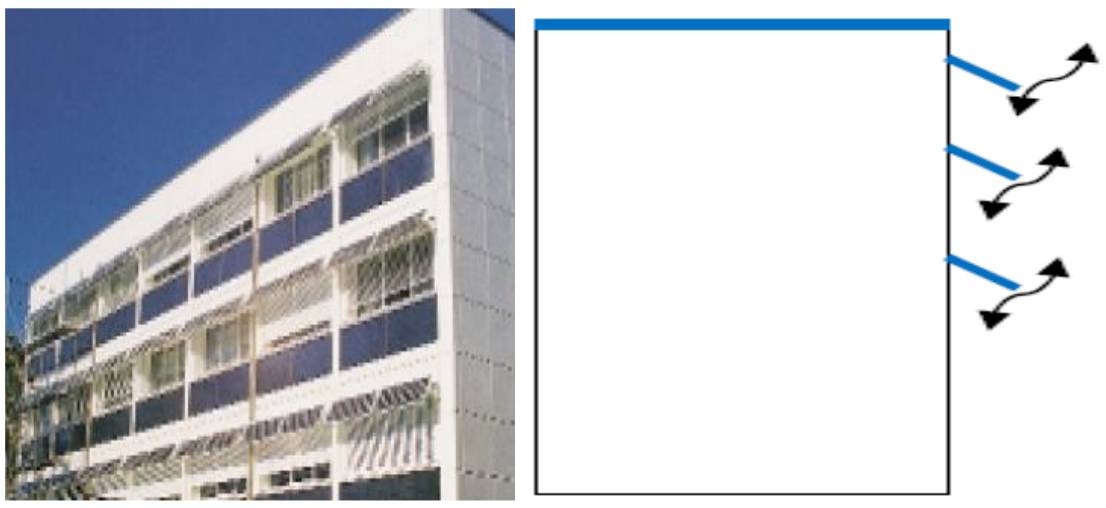

Figure 8. Moveable sunshades in a commercial office building, in Switzerland [62] 


\section{POSSIBILITY OF BIPV IN TROPICAL CLIMATES: CASE STUDY OF NIGERIA}

Nigeria is known for its tropical weather. Nigeria is situated approximately between latitude $4^{\circ}$ $14^{\circ} \mathrm{N}$ and longitude $2^{\circ}-15^{\circ} \mathrm{E}$ with a landmass of $9.24 \times 105 \mathrm{~km}^{2}$ and receives 6.25 hours of average daily sunshine, which ranges between 3.5 hours at the coastal areas and, in case of northern border, it turns out to be 9.0 hours [65]. The country is also known for its huge energy consumption, estimated as $15 \mathrm{x} 106 \mathrm{kWh}$ per year, according to 2001 index [65]. In addition, only $3.7 \%$ of Nigeria's land area is required to produce energy through solar means in comparison with conventional energy reserves of fossil fuel the that has been in process now [66].

The climate depends on the tropical to subtropical regions. Nigerian territory has two seasons: dry season, which lasts from October to March, and rainy season, from April to October. Northern region generally has hot and dry climate where the rainy season lasts from April to September. Whereas, in the southern region, the climate is generally hot and wet, and the rainy season extends from March to December. Therefore, in general, Nigeria enjoys a long dry season from December to March [67]. In the coastal area, the temperature may rise above $32^{\circ} \mathrm{C}$ in this time. Meanwhile, the north enjoys drier temperatures, ranged between $32^{\circ} \mathrm{C}$ and $42^{\circ} \mathrm{C}$. Generally, the humidity remains approximately $95 \%$ during this period of time [66].

Furthermore, in Nigeria, solar PV installations have steeply declined over the years and are forecasted to continue declining due to the struggles in the optimal harnessing of the solar electricity as a sustainable resource. The challenge remains to be the development of solar energy which solves technological installation problems, unclear governmental policy and politics, economic inefficiency in purchasing such power, lack of public awareness and cultural integration. It is already a fact that solar energy is the most abundant renewable resource in Nigeria because of the broad daylight which on average provides sunshine of 6.5 hour/day.

According to the literature [68], the best PV energy production results in Nigeria are achieved when using a $6^{0}$ tilting angle. In addition, it was suggested that between January and March, the best tilting angle will be $6^{\circ}, 24^{\circ}$ and $30^{\circ}$ respectively, and $0^{\circ}$ between April and September, and $18^{\circ}, 30^{\circ}$ and $36^{\circ}$ between October and December respectively. An energy amount of $192.70 \mathrm{~W} / \mathrm{m}^{2}$ can be produced with the adjustment of the tilting angle to its optimum angle, according to the month. It increases significantly about $3 \%$ in comparison to applying fixed angle, which produces $186.86 \mathrm{~W} / \mathrm{m}^{2}$.

To obtain maximum power output from solar PV, and since Nigeria is close to the equator, the solar collectors must be with a slight tilt of $6^{0}$ near the north or south, as shown in Figure 9. The maximum amount of energy year-round can be absorbed by inclining the solar panel at an angle closer to the latitude of the area as possible. These requirements are necessary for maximum power from BIPV.

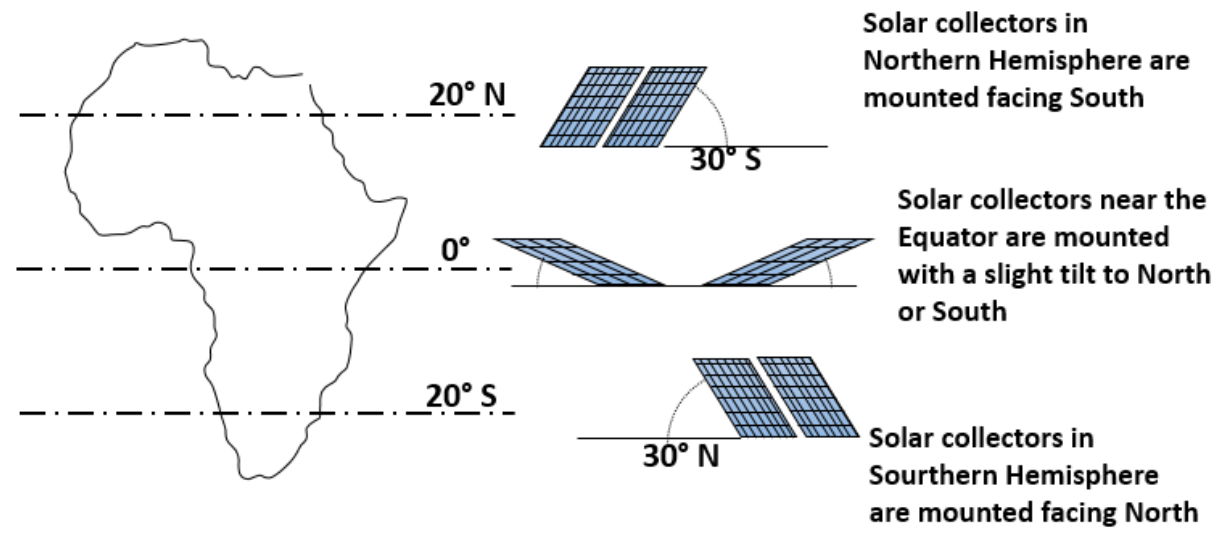

Figure 9. Mounting angles for fixed solar collectors in Africa [70]

Although BIPV has not been yet implemented in Nigeria, it is possible to introduce it in Nigerian buildings, if some issues are addressed. Such considerations include market failure and distortions, financial and economic constraints, lack of government and institutional policies and incentives, lack of awareness and public information. A large number of abandoned PV initiatives in Nigeria are should also be addressed, including all the already installed renewable energy infrastructures that are inefficient [69]. For BIPV to be fully implemented in a tropical region, like Nigeria, buildings must be constructed with materials having high 
thermal storage capability. There is also need for proper coating in roofing and ceilings. Solar tracking can also be an option to minimize direct sun radiation on buildings and increase the power output. Since these technologies are serving two functions (i.e. electricity and heating in buildings), they must conform to the codes and standards of both solar and building industry. To encourage builders and private investors to use BIPV, the governments should establish appropriate environmental policies and subsidies, with wellstructured feed-in tariffs. Also, for successful implementation of the BIPV technologies, the building engineers must have a good understanding of building design that includes solar technology because the solar elements must replace other building components and may reduce the overall building cost. This is vital, because, nowadays most solar works on building are done solely by solar engineers without any input from other building professionals.

\section{CONCLUSION}

This paper provides an overview of BIPV technologies. Specifically, the paper analyses the possible implementation of this scheme in tropical climatic conditions. First, the BIPV technology has been reviewed and several author contributions have been tabulated. Most BIPV concentrates on new designs to improve the efficiency, such as novel cooling techniques and system arrangements. Literature extensively reports the electric power generating capacity of BIPV, with efficiency reaching between 5-18\%, as well as many applications relating to roof top and façade BIPV.

In order to get higher power output from the BIPV, certain factors need to be considered, for example, slope of the PV, shadowing effect, temperature and the direction of the building. A lot of research on BIPV shows simulation and computational analysis because it is easier and cheaper for evaluation and encouraging results have been reported. In general, silicon-based PV modules have been applied to BIPV applications. Recently, there have been rising interests in BIPV systems with low cost and investment feasibility. Recent researches proposed the application of dye-sensitive solar cell technology as a solution for BIPV technology.

The BIPV-thermal is another system that made tremendous progress due to its high cost of implementation. It has the advantage of providing both power and heating systems for buildings. Several researches proposed that it is a promising technology for the future.

After reviewing the literature, some of the lessons that tropical climate regions can learn from the BIPV include: (1) In order to fully implement BIPV with high efficiency, certain studies must be done relating to electrical load demand, predicted PV output, location of the buildings and its integration and constraints associated with roof design, (2) To obtain maximum power output from solar PV the solar collectors must be tilted to the correct position, (3) To implement BIPV, design criteria such as safety, efficiency, durability, flexibility and construction issues need to be considered, (4) To be able to implement BIPV, the government must train electricians and carpenters on PV installations, (5) To implement a good system, the BIPV roofing must perform same function as normal roofing, that is, noise protection, water tightness, insulation and climate protection, (6) As practiced around the world, each country should establish design standards for the BIPV. These standards shall provide protection from wind, precipitation, temperature and solar irradiation for greater comfort, (7) For a tropical region like Nigeria, thermal comfort for residents must be considered when designing BIPV technology. If possible, techniques to reduce thermal heating on buildings surfaces must be implemented.

\section{ACKNOWLEDGEMENTS}

The authors would like to thank Ministry of Higher Education (MOHE), Malaysia via Universiti Teknologi Malaysia (UTM) (Research cost centre no. Q.K130000.3556.06G43), the Agencia Nacional de Investigación y Desarrollo (through the project Fondecyt regular 1200055 and the project Fondef ID19I10165), project PI_m_19_01 (UTFSM) and by Universiti Kuala Lumpur under the Short Term Research Grant (STRG) STR18022.

\section{REFERENCES}

[1] S. ed-D. Fertahi, T. Bouhal, F. Gargab, A. Jamil, T. Kousksou, and A. Benbassou, "Design and thermal performance optimization of a forced collective solar hot water production system in Morocco for energy saving in residential buildings," Sol. Energy, vol. 160, pp. 260-274, Jan. 2018.

[2] C. Koroneos and M. Tsarouhis, "Exergy analysis and life cycle assessment of solar heating and cooling systems in the building environment," J. Clean. Prod., vol. 32, pp. 52-60, Sep. 2012. 
[3] M. A. S. Jamaluddin et al., "Potential of floating solar technology in Malaysia," International Journal of Power Electronics and Drive System (IJPEDS), vol. 10, no. 3, pp. 1638-1644, Sep. 2019.

[4] Swiss Federal Commission for Monument Preservation, Guidelines for the preservation of built heritage in Switzerland. Zurich, Switzerland: vdf Hochschulverlag AG an der ETH Zürich, 2007.

[5] M. E. Amran et al., "Photovoltaic-integrated review and expansion need in green building landscape for bridging the malaysian RE policy," Indonesian Journal of Electrical Engineering and Computer Science, vol. 17, no. 1, pp. 27-35, Jan. 2020.

[6] M. E. Amran et al., "Optimal distributed generation in green building assessment towards line loss reduction for Malaysian public hospital," Bulletin of Electrical Engineering and Informatics, vol. 8, no. 4, pp. 1180-1188, 2019.

[7] A. G. Hestnes, "Building integration of solar energy systems," Sol. Energy, vol. 67, no. 4-6, pp. 181-187, 1999.

[8] APERC, "Towards zero-emission efficient and resilient buildings: Global Status Report 2016," Global Alliance for Buildings and Construction (GABC), pp. 1-32, 2001

[9] D. Ma and Y.-B. Xue, "Solar energy and residential building integration technology and application," Int. J. Clean Coal Energy, vol. 2, no. 2, pp. 8-12, 2013.

[10] Í. P. dos Santos and R. Rüther, "The potential of building-integrated (BIPV) and building-applied photovoltaics (BAPV) in single-family, urban residences at low latitudes in Brazil," Energy Build., vol. 50, pp. 290-297, 2012.

[11] S. S. S. Baljit, H.-Y. Chan, and K. Sopian, "Review of building integrated applications of photovoltaic and solar thermal systems," J. Clean. Prod., vol. 137, pp. 677-689, 2016.

[12] J. H. Scofield, "Early performance of a green academic building," ASHRAE Trans., vol. 108, no. 2, pp. 1214-1230, 2002.

[13] S. El Gindi, A. R. Abdin, and A. Hassan, "Building integrated Photovoltaic Retrofitting in office buildings," Energy Procedia, vol. 115, pp. 239-252, Jun. 2017.

[14] A. F. Fishbach, "Inside the BIPV Market," EC\&M, 2017. [Online]. Available: https://www.ecmweb.com/contractor/inside-bipv-market. [Accessed: 05-Sep-2018].

[15] T. Zhang, M. Wang, H. Yang, T. Zhang, M. Wang, and H. Yang, "A review of the energy performance and lifecycle assessment of building-integrated photovoltaic (BIPV) systems," Energies, vol. 11, no. 11, p. 3157, 2018.

[16] T. James, A. Goodrich, M. Woodhouse, R. Margolis, and S. Ong, "Building-Integrated Photovoltaics (BIPV) in the Residential Sector: An Analysis of Installed Rooftop System Prices,” USA, 2011.

[17] S. Lok, M. Shin, J. Baltazar, and J. Kim, "Energy benefits from semi-transparent BIPV window and daylightdimming systems for IECC code-compliance residential buildings in hot and humid climates," Sol. Energy, vol. 155, pp. 291-303, 2017.

[18] O. Ayadi and S. Al-dahidi, "Comparison of solar thermal and solar electric space heating and cooling systems for buildings in different climatic regions," Sol. Energy, vol. 188, no. June, pp. 545-560, 2019

[19] M. J. Sorgato, K. Schneider, and R. Rüther, "Technical and economic evaluation of thin- fi lm CdTe buildingintegrated photovoltaics ( BIPV ) replacing façade and rooftop materials in office buildings in a warm and sunny climate," Renew. Energy, vol. 118, pp. 84-98, 2018.

[20] M. A. Ekoe a Akata, D. Njomo, and B. Mempouo, "The effect of building integrated photovoltaic system (Bipvs) on indoor air temperatures and humidity (Iath) in the tropical region of Cameroon," Futur. Cities Environ., vol. 1, no. 1, pp. 1-10, Aug. 2015.

[21] Z. Gou et al., "An investigation of thermal comfort and adaptive behaviors in naturally ventilated residential buildings in tropical climates: A pilot study," Buildings, vol. 8, no. 1, p. 5, Jan. 2018.

[22] G. Aaditya and M. Mani, "Climate-responsive integrability of building-integrated photovoltaics," Int. J. LowCarbon Technol., vol. 8, no. 4, pp. 271-281, Dec. 2013.

[23] P. Gut and D. Ackerknecht, Climate Responsive Building: Appropriate Building Construction in Tropical and Subtropical Regions. University of California, Berkeley, USA: SKAT, 1993.

[24] A. Ghazali M. and A. M. Abdul Rahman, "The performance of three different solar panels for solar electricity applying solar tracking device under the Malaysian climate condition," Energy Environ. Res., vol. 2, no. 1, p. 235, May 2012.

[25] A. F. Lawal, "Assessment of Public Building Designs for Energy Conservation in Southwestern Nigeria," Ph.D. dissertation, Obafemi Awolowo University, Ile-Ife. Nigeria, 2008.

[26] A. Abubakar Mas'ud, A. V. Wirba, F. Muhammad-Sukki, I. Abubakar Mas'ud, A. B. Munir, and N. Md Yunus, "An assessment of renewable energy readiness in Africa: Case study of Nigeria and Cameroon," Renew. Sustain. Energy Rev., vol. 51, pp. 775-784, Nov. 2015.

[27] Y. S. Mohammed, M. W. Mustafa, N. Bashir, and A. S. Mokhtar, "Renewable energy resources for distributed power generation in Nigeria: A review of the potential," Renew. Sustain. Energy Rev., vol. 22, pp. 257-268, 2013.

[28] J. Amankwah-Amoah, "Solar energy in Sub-Saharan Africa: The challenges and opportunities of technological leapfrogging," Thunderbird Int. Bus. Rev., vol. 57, no. 1, pp. 15-31, Jan. 2015.

[29] E. Biyik et al., "A key review of building integrated photovoltaic (BIPV) systems," Eng. Sci. Technol. an Int. J., vol. 20, no. 3, pp. 833-858, Jun. 2017.

[30] A. Henemann, "BIPV: Built-in solar energy," Renew. Energy Focus, vol. 9, no. 6, pp. 14-19, Nov. 2008.

[31] S. F. Barkaszi and J. P. Dunlop, "Discussion of strategies for mounting photovoltaic arrays on rooftops," in Proceedings of Solar Forum, pp. 1-6, 2001.

[32] J. J. Bloem, C. Lodi, J. Cipriano, and D. Chemisana, "An outdoor test reference environment for double skin applications of building integrated photoVoltaic systems," Energy Build., vol. 50, pp. 63-73, Jul. 2012.

[33] B. Petter Jelle, C. Breivik, and H. Drolsum Røkenes, "Building integrated photovoltaic products: A state-of-the-art review and future research opportunities," Sol. Energy Mater. Sol. Cells, vol. 100, pp. 69-96, May 2012. 
[34] S. Strong, "Building Integrated Photovoltaics (BIPV)," Whole Building Design Guide (WBDG), 2016. [Online]. Available: https://www.wbdg.org/resources/building-integrated-photovoltaics-bipv. [Accessed: 05-Sep-2018].

[35] C. L. Cheng, C. Y. Chan, and C. L. Chen, "Empirical approach to BIPV evaluation of solar irradiation for building applications," Renew. Energy, vol. 30, no. 7, pp. 1055-1074, Jun. 2005.

[36] T. T. Chow, J. W. Hand, and P. A. Strachan, "Building-integrated photovoltaic and thermal applications in a subtropical hotel building," Appl. Therm. Eng., vol. 23, no. 16, pp. 2035-2049, Nov. 2003.

[37] M. J. Jiménez, H. Madsen, J. J. Bloem, and B. Dammann, "Estimation of non-linear continuous time models for the heat exchange dynamics of building integrated photovoltaic modules," Energy Build., vol. 40, no. 2, pp. 157-167, Jan. 2008.

[38] S. Pantic, L. Candanedo, and A. K. Athienitis, "Modeling of energy performance of a house with three configurations of building-integrated photovoltaic/thermal systems," Energy Build., vol. 42, no. 10, pp. 1779-1789, Oct. 2010

[39] C. D. Corbin and Z. J. Zhai, "Experimental and numerical investigation on thermal and electrical performance of a building integrated photovoltaic-thermal collector system," Energy Build., vol. 42, no. 1, pp. 76-82, Jan. 2010.

[40] C. Peng, Y. Huang, and Z. Wu, "Building-integrated photovoltaics (BIPV) in architectural design in China," Energy Build., vol. 43, no. 12, pp. 3592-3598, Dec. 2011.

[41] J. Urbanetz, C. D. Zomer, and R. Rüther, "Compromises between form and function in grid-connected, buildingintegrated photovoltaics (BIPV) at low-latitude sites," Build. Environ., vol. 46, no. 10, pp. 2107-2113, Oct. 2011.

[42] O. Zogou and H. Stapountzis, "Experimental validation of an improved concept of building integrated photovoltaic panels," Renew. Energy, vol. 36, no. 12, pp. 3488-3498, Dec. 2011.

[43] J.-H. Yoon, J. Song, and S.-J. Lee, "Practical application of building integrated photovoltaic (BIPV) system using transparent amorphous silicon thin-film PV module," Sol. Energy, vol. 85, no. 5, pp. 723-733, May 2011.

[44] G. Ban-Weiss, C. Wray, W. Delp, P. Ly, H. Akbari, and R. Levinson, "Electricity production and cooling energy savings from installation of a building-integrated photovoltaic roof on an office building," Energy Build., vol. 56, pp. 210-220, Jan. 2013.

[45] J. Han, L. Lu, J. Peng, and H. Yang, "Performance of ventilated double-sided PV façade compared with conventional clear glass façade," Energy Build., vol. 56, pp. 204-209, Jan. 2013.

[46] M. Drif, A. Mellit, J. Aguilera, and P. J. Pérez, "A comprehensive method for estimating energy losses due to shading of GC-BIPV systems using monitoring data," Sol. Energy, vol. 86, no. 9, pp. 2397-2404, Sep. 2012.

[47] S. Wittkopf, S. Valliappan, L. Liu, K. S. Ang, and S. C. J. Cheng, "Analytical performance monitoring of a 142.5 kWp grid-connected rooftop BIPV system in Singapore," Renew. Energy, vol. 47, pp. 9-20, Nov. 2012.

[48] P. R. Defaix, W. G. J. H. M. van Sark, E. Worrell, and E. de Visser, "Technical potential for photovoltaics on buildings in the EU-27," Sol. Energy, vol. 86, no. 9, pp. 2644-2653, Sep. 2012.

[49] H. Wei, J. Liu, and B. Yang, "Cost-benefit comparison between Domestic Solar Water Heater (DSHW) and Building Integrated Photovoltaic (BIPV) systems for households in urban China," Appl. Energy, vol. 126, pp. 4755, Aug. 2014.

[50] C. S. P. López and M. Sangiorgi, "Comparison assessment of BIPV façade semi-transparent modules: Further insights on human comfort conditions," Energy Procedia, vol. 48, pp. 1419-1428, Jan. 2014.

[51] T. Yang and A. K. Athienitis, "Experimental investigation of a two-inlet air-based building integrated photovoltaic/thermal (BIPV/T) system," Appl. Energy, vol. 159, pp. 70-79, Dec. 2015.

[52] E. Bigaila, E. Rounis, P. Luk, and A. Athienitis, "A Study of a BIPV/T Collector Prototype for Building Façade Applications," Energy Procedia, vol. 78, pp. 1931-1936, Nov. 2015.

[53] R. Eke and C. Demircan, "Shading effect on the energy rating of two identical PV systems on a building façade," Sol. Energy, vol. 122, pp. 48-57, Dec. 2015.

[54] V. Timchenko, O. A. Tkachenko, S. Giroux-Julien, and C. Ménézo, "Numerical and Experimental Investigation of Natural Convection in Open-Ended Channels with Application to Building Integrated Photovoltaic (BIPV) Systems," EPJ Web Conf., vol. 92, p. 01002, May 2015.

[55] M. Ritzen, Z. Vroon, R. Rovers, C. Geurts, and B. Blocken, "Real Life Lab BIPV field testing in the Netherlands," in 2015 IEEE 42nd Photovoltaic Specialist Conference (PVSC), pp. 1-5, 2015.

[56] F. Chen and H. Yin, "Fabrication and laboratory-based performance testing of a building-integrated photovoltaicthermal roofing panel," Appl. Energy, vol. 177, pp. 271-284, Sep. 2016.

[57] W. Lu, Y. Wu, and P. Eames, "Design and development of a building façade integrated asymmetric compound parabolic photovoltaic concentrator (BFI-ACP-PV),” Appl. Energy, vol. 220, pp. 325-336, Jun. 2018.

[58] M. Debbarma, K. Sudhakar, and P. Baredar, "Comparison of BIPV and BIPVT: A review," Resour. Technol., vol. 3, no. 3, pp. 263-271, Sep. 2017.

[59] D. Attoye et al., "A conceptual framework for a building integrated photovoltaics (BIPV) educativecommunication approach," Sustainability, vol. 10, no. 10, p. 3781, Oct. 2018.

[60] G. Kiss and J. Kinkead, "Optimal Building-Integrated Photovoltaic Applications," Colorado, USA, 1995.

[61] B. W. Olesen, "International standards for the indoor environment," Indoor Air, vol. 14, no. s7, pp. 18-26, 2004.

[62] R. Thomas, Photovoltaics and architecture, 1st ed. London, UK: Spon Press, 2001.

[63] HORISUN, "PVdatabase," 2018. [Online]. Available: http://www.pvdatabase.org/index.php. [Accessed: 16-Oct2018].

[64] S. Wittkopf, N. Wong, and W. Hess, Potential of BIPV in Existing Urban High-Rise Housing in Singapore. Singapore: CASA, 2004. 
[65] J. O. Oji, N. Idusuyi, T. O. Aliu, M. O. Petinrin, O. A. Odejobi, and A. R. Adetunji, "Utilization of solar energy for power generation in Nigeria," Int. J. Energy Eng., vol. 2, no. 2, pp. 54-59, 2012.

[66] M. Shaaban and J. O. Petinrin, "Renewable energy potentials in Nigeria: Meeting rural energy needs," Renew. Sustain. Energy Rev., vol. 29, pp. 72-84, Jan. 2014.

[67] F. G. Akinboro, L. A. Adejumobi, and V. Makinde, "Solar energy installation in Nigeria: Observations, prospect, problems and solution,” Transnatl. J. Sci. Technol., vol. 2, no. 4, pp. 73-84, 2012.

[68] Y. Udoakah and N. Okpura, "Determination of optimal tilt angle for maximum solar insolation for PV systems in Enugu-Southern Nigeria," Niger. J. Technol., vol. 34, no. 4, pp. 838-843, Sep. 2015.

[69] C. O. Nwokocha, U. K. Okoro, and C. I. Usoh, "Photovoltaics in Nigeria - Awareness, attitude and expected benefit based on a qualitative survey across regions," Renew. Energy, vol. 116, pp. 176-182, Feb. 2018.

[70] O. Awogbemi, I. O. Oluwaleye, and C. A. Komolafe, "A survey of solar energy utilization for sustainable development In Nigeria,” J. Multidiscip. Eng. Sci. Technol. , vol. 2, no. 2, pp. 1716-1724, 2015.

\section{BIOGRAPHIES OF AUTHORS}
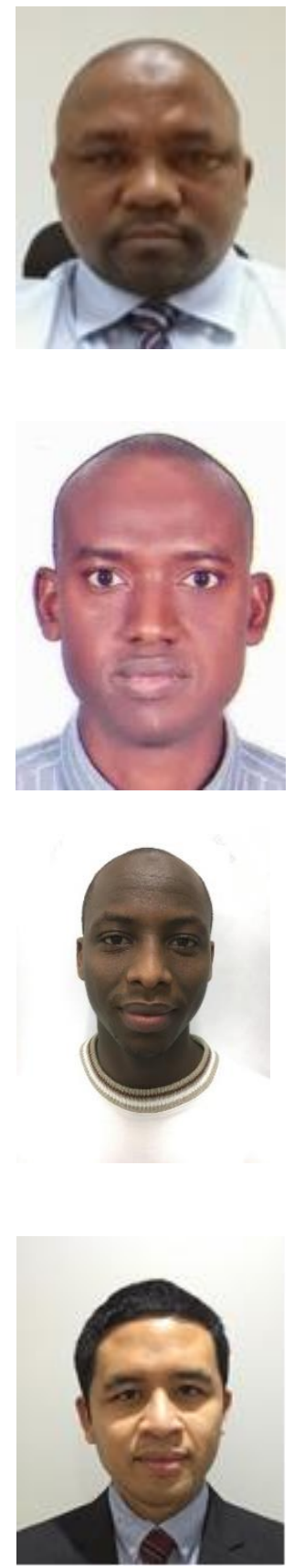

Mohammed Abdullahi Mu'azu is currently an Assistant Professor in department of Civil Engineering, College of Engineering, University of Hafr Al Batin (Kingdom of Saudi Arabia). He graduated in 1999 with a B. Eng. Civil Engineering from Bayero University, Kano (Nigeria), with Master's degree in Civil Engineering from the famous Ahmadu Bello University, Zaria (Nigeria). He later joined Universiti Teknologi, Malaysia where he obtained his $\mathrm{PhD}$ in Civil Engineering. He worked previously with the following institutions of higher learning as follows; Federal University of Technology, Minna (Nigeria), Universiti Tecknologi, Malaysia and Jubail University College (Kingdom of Saudi Arabia). He was involved in teaching and research apart from administrative duties including been a chairperson and course director of a department. He was also deeply involved in quality assurance and accreditations committees, coupled with a quite number of publications in reputable journals and conferences to his name.

Abdullahi Abubakar Mas'ud, (PhD, CEng, MIET) received his BEng. degree in Electrical Engineering from Ahmadu Bello University (ABU) in 1999. Subsequently, he pursued his Masters degree in the same discipline at ABU and graduated in 2003. He also obtained a PhD in Electrical Engineering in 2013 from the Glasgow Caledonian University, Scotland, UK, under the supervision of Prof. Brian Stewart and Prof. Scott McMeekin. In 2002 he became an assistant lecturer in the Faculty of Engineering at the Ahmadu Bello University, Zaria, Nigeria. In 2013 he joined Jubail Industrial College, Saudi Arabia, and is currently an Associate Professor in the Department of Electrical and Electronic Engineering. He has published a number of papers in high impact factor journals and conference proceedings in the area of high voltage partial discharge and renewable energy. He is a Chartered Engineer and a Member of the IET, International association of Engineers and a registered Engineer (COREN) Nigeria.

Ibrahim Mas'ud (MNSE, MNIMechE) received his BEng. degree in Mechanical Engineering from Bayero University Kano (BUK) in 2009. Subsequently, he pursued his Master's degree in the same discipline at Shibaura Institute of Technology, Tokyo Japan. He has added several international conferences and got some outstanding awards in his research projects. In 2010 he joined he National Agency for Science and Engineering Infrastructure (NASENI) Nigeria as a renewable Energy Engineer where he is currently a senior research engineer in the field of renewable energy and other emerging technologies. He is a registered Engineer (COREN) Nigeria.

Firdaus Muhammad-Sukki (MEng, PhD, CEng, MIET, ACGI, FHEA) is currently a Lecturer at the School of Engineering and the Built Environment, Edinburgh Napier University. His research interest is in the area of renewable energy technology and policies and sustainable resources. He has secured multiple grants from the UK and international funding agencies such as Innovate UK, Scottish Funding Council, British Council - Newton Fund, Ministry of Higher Education Malaysia, Universiti Teknologi Malaysia etc. He also carried out a number of nontechnical research including market trend and financial analysis related to renewable technologies for various countries. He has published numerous articles in high impact factor journals (e.g. Nature, Renewable \& Sustainable Energy Reviews, Applied Energy, etc.), as well as presenting in various conferences related to his area. Prior to joining the academia, he was a communication engineer in Malaysia's largest telecommunication company. 


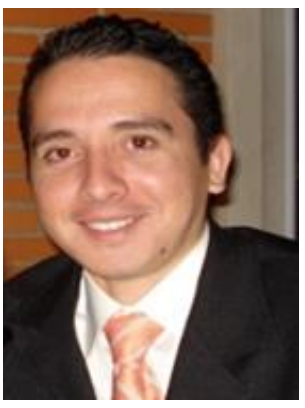

Jorge Alfredo Ardila Rey was born in Santander, Colombia, in 1984. He received the B.Sc. degree in mechatronic engineering from Universidad de Pamplona, Pamplona Colombia in 2007. He received the Specialist Officer degree in Naval Engineering from Escuela Naval Almirante Padilla, Cartagena, Colombia in 2008. He received the M.Sc. and Ph.D. degrees in electrical engineering from Universidad Carlos III de Madrid (UC3M) in 2012 and 2014, respectively. He was an Automatic Control Engineer of ARC Almirante Padilla from 2008 to 2010. From 2010 to 2014, he worked in the Department of Electrical Engineering and the High-Voltage Research and test Laboratory (LINEALT) at UC3M. He is currently working as a Professor at the Department of Electrical Engineering of Universidad Técnica Federico Santa María at Santiago of Chile. His research interests include partial discharges, insulation systems diagnosis and instrumentation and measurement techniques for high frequency currents.

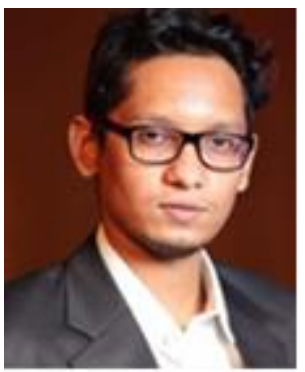

Ridoan Karim is a Lecturer at the Department of Business Law and Taxation, School of Business, Monash University Malaysia. He has taught and researched in the fields of business and international trade law. Being a passionate researcher and academic, Ridoan has widely published in peer-reviewed journals and presented papers in several national and international conferences in his areas of interest, i.e. 'legal and regulatory aspects of energy', 'science, technology and law', 'privacy and data protection law', 'human rights law', 'health and medical law', 'legal research', and 'Asian and comparative law', etc. Ridoan also regularly writes columns on a wide range of national and international legal and non-legal issues widely circulated in national and international newspapers. Ridoan had acted as a Consultant and Fellow in projects funded by the University of Malaya, Malaysia.

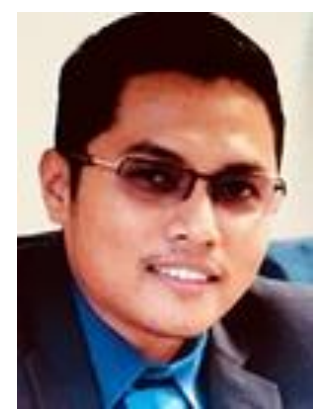

Ahmad Shakir Mohd Saudi is a Senior Lecturer at Institute of Medical Science Technology, Universiti Kuala Lumpur, Malaysia. He is very active in research and was being appointed as Principal Research Investigator of Environmental Health Research Cluster, (EHReC- UniKL) in 2017. His PhD degree in Environmental Forensic Science with the study on the development of flood risk index. He is an expert in Chemometric techniques and data modeling. He has published numerous of book and academic papers that related with big data, risk analysis and environmental data modeling. Recently, he is working on with biomedical science research that focused on the development of gadget that able to alarm an early warning for Retinopathy diseases among diabetic patients. He was being appointed as an editorial board by several high impact publishers as an appreciation of his high quality of work in research. His contribution in his field also has been recognized from several local universities in Malaysia. This recognition was proven since he was being appointed as a subject matter expert under Open University Malaysia and allied co- researcher members under Cyber Security and System Unit, Universiti Sains Islam Malaysia.

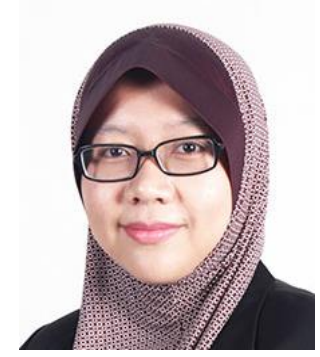

Nurul Aini Bani is a senior lecturer in the Razak Faculty of Technology and Informatics, Universiti Teknologi Malaysia Kuala Lumpur. She received her M.Eng degree in Electrical Engineering from University of Southampton, UK in 2006 where she received two academic awards for outstanding academic performance. She received her $\mathrm{PhD}$ degree in Electrical Engineering from Universiti Teknologi Malaysia (UTM). Her research interests include polymeric insulation material, space charge measurement, high voltage cable, renewable energy, rural technology and rehabilitation engineering. Her current work concentrates on developing low cost renewable energy system for rural and remote area, namely solar concentrator and saltwater battery. She also currently works on the development of an IoT system for monitoring health status especially for post stroke and post brain injury patient. She has authored and coauthored several papers in various technical and high impact factor journals as well as conference proceedings. She also actively involves in many community programs.

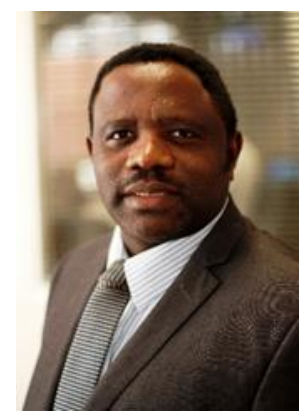

Asan Vernyuy Wirba, has a career in leadership and Management for over 14 years, and Associate Professor of leadership and Management at the Department of Management and Information Technology (MIT), Jubail Industrial College (JIC), Royal Commission, Jubail Industrial City, Saudi Arabia, and has a wealth of experience in teaching, training, research, business, consulting, great interest in solar energy and academic management. He holds a Ph.D. from The University of Manchester, UK. 